\title{
Scholarly

\section{Sequence and Phylogenetic Analysis of Three Isolates of Avian Influenza H9N2 from Chickens in Southern China}

\author{
Zhixun Xie, ${ }^{1}$ Jianbao Dong, ${ }^{1}$ Xiaofei Tang, ${ }^{1}$ Jiabo Liu, ${ }^{1}$ Mazhar I. Khan, ${ }^{2}$ \\ Yaoshan Pang, ${ }^{1}$ Xianwen Deng, ${ }^{1}$ and Zhiqin Xie ${ }^{1}$ \\ ${ }^{1}$ Department of Biotechnology, Guangxi Veterinary Research Institute, 51 You Ai Road, Nanning, Guangxi 530001, China \\ ${ }^{2}$ Department of Pathobiology and Veterinary Science, University of Connecticut, 61 North Eagleville Road, \\ Storrs, CT 06269-3089, USA
}

Correspondence should be addressed to Mazhar I. Khan, mazhar.khan@uconn.edu

Received 27 February 2008; Accepted 7 April 2008

\begin{abstract}
Three isolates of H9N2 influenza virus were isolated from chickens in Guangxi province. In this study, eight full-length genes of each of the H9N2 isolates were obtained and sequenced. Sequence analysis and phylogenetic studies were conducted by comparing eight genes of each isolate with those of the available H9N2 strains at GenBank. Results showed a high degree of homology between the Guangxi isolates and isolates from Guangdong and Jiangsu provinces, suggesting that Guangxi isolates originated from the same source. However, the eight genes of these three isolates from Guangxi were not in the same sublineages in the phylogenic trees, which suggest that they were products of natural reassortment between H9N2 avian influenza viruses from different sublineages. The 9 nucleotides ACAGAGATA encoding amino acids T, E, I were absent between nucleotide 205 and 214 in the open reading frame of NA genes in the Guangxi isolates. AIV strains that infect human have, in their HA proteins, leucine at position 226. The analysis of deduced amino acid sequence of HA proteins showed that the position 226 of these isolates was glycine instead of leucine, suggesting that these three isolates differ from H9N2 AIV strains isolated from human infections.
\end{abstract}

Copyright ( $\odot 2008$ Zhixun Xie et al. This is an open access article distributed under the Creative Commons Attribution License, which permits unrestricted use, distribution, and reproduction in any medium, provided the original work is properly cited.

\section{Introduction}

Avian influenza virus (AIV) belongs to the Orthomyxoviridae family of RNA viruses. It is an enveloped virus with a helical nucleocapsid and eight segments of single-stranded negative-sense RNA. The envelope contains the haemagglutinin (HA) and neuraminidase (NA) proteins, of which there are currently $16 \mathrm{HA}(\mathrm{H} 1-\mathrm{H} 16)$ and 9 NA (N1-N9) subtypes $[1,2]$. The H9N2 subtype that is worldwide spread in poultry could infect humans and is prevalent in China [38]. The first outbreak of disease attributed to H9N2 in China happened in Guangdong province in 1994. Other strains of this subtype were subsequently isolated $[6,7,9,10]$.

Studies to characterize these strains were focused on the HA genes for one of the surface viral proteins that plays a crucial role in the pathogenicity [10]. Recent studies characterized the nonstructural [11] and neuraminidase genes [12] of H9N2 viruses in China. Others showed that some novel reassortant $\mathrm{H} 9 \mathrm{~N} 2$ influenza viruses may possess certain genes from $\mathrm{H} 5$ subtype viruses $[7,13,14]$. In this study, we have characterized three strains of H9N2 influenza viruses that were isolated from chicken farms in Guangxi province. All eight full-length genes of these isolates were obtained individually by means of RT-PCR. Sequence analysis and phylogenetic study were conducted by comparing the eight genes of each isolate with sequences available in Genbank (H9N2 isolates from 1966-2005).

\section{Materials and Methods}

2.1. Viruses. Three isolates of $\mathrm{H} 9 \mathrm{~N} 2$ subtype influenza viruses, A/Chicken/Guangxi/1/00 (C/GX/1/00), A/Chicken/ Guangxi/14/00 (C/GX/14/00), A/Chicken/Guangxi/17/00 $(\mathrm{C} / \mathrm{GX} / 17 / 00)$ were recovered from chickens in different areas of Guangxi province during 2000 and 2001. Initial isolation was performed in 10-day-old specific-pathogenfree $(\mathrm{SPF})$ embryonated chicken eggs. Identification of the viruses was determined by standard hemagglutinationinhibition and neuraminidase-inhibition tests [15]. Allantoic 
TABLE 1: The nucleotide sequences of the eight pairs of specific primers for $\mathrm{H} 9 \mathrm{~N} 2$ subtypes.

\begin{tabular}{|c|c|}
\hline Gene & Sequence of primers \\
\hline \multirow{2}{*}{ HA } & F: 5' -AGCAAAAGCAGGGGAATTTCAC-3' \\
\hline & R: 5'-AGTAGAAAACAAGGGTGTTTTTGC-3': \\
\hline \multirow{2}{*}{ NA } & F: 5'-AAAAGCAGGCAAACCATTTGA-3' \\
\hline & R: 5' -TTTTCATGAAGGACAAGCTAA-3' \\
\hline \multirow{2}{*}{ NP } & F: 5'-GCAGGTAGATAATCACTCACTG-3' \\
\hline & R: 5' -AGTAGAAACAAGGGTATTTTT-3' \\
\hline \multirow{2}{*}{ M } & F: 5'-AGCAAAAGCAGGTAGATGTTTAAAG-3' \\
\hline & R:5'-AGTAGAAACAAGGTAGTTTTTTAC-3' \\
\hline \multirow{2}{*}{ NS } & $\mathrm{F}: 5^{\prime}$-AAAGCAAGGGTGACAAAGACAT-3' \\
\hline & R: 5'-TAGAAACAAGGGTGTTTTTTATCA-3' \\
\hline \multirow{2}{*}{$\mathrm{PA}$} & F: $5^{\prime}$-AGCAAAAGCAGGTACTGAT-3' \\
\hline & R: 5' -AGTAGAAACAAGGTACTTTT-3' \\
\hline \multirow{2}{*}{$\mathrm{Pb} 1$} & F: 5'-AAAAGCAGGCAAACCATTTGA-3' \\
\hline & R: 5'-TTTTCATGAAGGACAAGCTAA-3' \\
\hline \multirow{2}{*}{$\mathrm{Pb} 2$} & F: 5'-AAAAGCAGGTCAATTATATTC-3' \\
\hline & R: 5' -AAGGTCGTTTTTAAACTATTCA-3' \\
\hline
\end{tabular}

fluids were harvested from SPF egg-passaged viruses and used as stock viruses for further analysis.

2.2. RNA Extraction and RT-PCR. Viral RNA was obtained from allantoic fluid by TRIzol extraction according to the method described by Xie et al. [16]. The concentrations of RNA were determined by spectrophotometry using the UV2501PC (Shimadzu Cooperation, Tokyo, Japan) and then stored at $-20^{\circ} \mathrm{C}$. Reverse transcription was done by using random primers with RNA PCR (AMV) V3.1 kit (TaKaRa Biotechnology, Dalian, China). Amplification of the eight full-length genes was carried out by PCR as described previously by Xie et al. [16] using pairs of specific primers as described in Table 1 . The reaction was carried out at $30^{\circ} \mathrm{C}$ for 5 minutes followed by 60 minutes incubation at $37^{\circ} \mathrm{C}$. PCR was performed in a reaction mixture of $50 \mu \mathrm{L}$ containing master mix buffer with dNTPs, 50-time Advantage 2 polymerase (Clontech Mountain View, California, USA), $10 \mu \mathrm{M}$ of each specific primer, and $200 \mathrm{ng}$ cDNA template. The PCR condition for the amplification of $\mathrm{Pb} 2, \mathrm{~Pb} 1$, and $\mathrm{HA}$ was $95^{\circ} \mathrm{C}$ for 2 minutes denaturation, and 35 cycles of $95^{\circ} \mathrm{C}$ for 30 seconds, $62^{\circ} \mathrm{C}$ for 45 seconds (annealing), and $68^{\circ} \mathrm{C}$ for 3 minutes, followed by $70^{\circ} \mathrm{C}$ for 10 minutes final extension. The PCR condition for the amplification of NP, NA, M, and NS genes was the same as above, except that the annealing temperature was reduced to $60^{\circ} \mathrm{C}$ for NP and NA genes and $58^{\circ} \mathrm{C}$ for $\mathrm{M}$ and $\mathrm{NS}$ genes.

2.3. Sequence Analysis. All PCR products were subjected to electrophoresis in a $1 \%(\mathrm{w} / \mathrm{v})$ agarose gel. DNA fragments of the expected length were extracted and purified with DNA Glass-milk Rapid Purification Kit (MK001-2, BioDev, Beijing, China). The purified DNA fragments were cloned into pMD18-T easy vector according to the manufacturer protocol (TaKaRa Biotechnology Co. Ltd., Dalian, China).
Three clones of each of the 8 fragments were sequenced by the Takara Biotechnology Co. Ltd., Dalian, China. DNA sequences of eight genes were compared with the GenBank database. DNA sequences of each cloned gene were repeated twice to confirm the similarity of sequence data. The nucleotide sequences obtained in this study are available in the GenBank database under accession numbers: DQ485205 to DQ485228.

2.4. Phylogenetic Analysis. The DNA sequences of the eight genes of three Guangxi H9N2 subtypes were compared initially with the Megalign program of the package with the Clustal alignment algorithm (DNASTAR Inc., Madison, Wis, USA) against the twelve H9N2 virus sequences as listed in Table 3. Pairwise sequence alignments were also performed with the Clustal alignment algorithm in the Megalign program to determine sequence similarity and phylogenetic relationship of different H9N2 subtype viruses. The ancestral relationships within eight genes among the fifteen H9N2 subtypes are presented in a phylogenetic tree created by the Megalign program.

\section{Results}

3.1. Result of Sequencing. The lengths of all genes were obtained for the three isolates (C/GX/1/00, C/GX/14/00, and C/GX/17/00): HA $1.7 \mathrm{~kb}$, NA $1.4 \mathrm{~kb}, \mathrm{NP} 1.5 \mathrm{~kb}, \mathrm{M} 1.0 \mathrm{~kb}$, NS $890 \mathrm{bp}, \mathrm{PA} 2.2 \mathrm{~kb}, \mathrm{~Pb} 12.3 \mathrm{~kb}, \mathrm{~Pb} 22.3 \mathrm{~kb}$. BLAST software and Megalign programs were used to determine the sequence similarity of the eight genes from the three isolates, as shown in Table 2.

3.2. Comparison of Nucleotide and Deduced Amino Acid Sequences of Eight Genes. In this study, the nucleotide sequences obtained from these three H9N2 isolates were compared with those of all the available full-length genomes of H9N2 strains isolated during 1966-2005 deposited in the GenBank database. Results indicate that nucleotide homology among these isolates with HA genes is between $82.6 \%$ to $99.3 \%$; for NA genes is between $91.8 \%$ to $97.7 \%$; for NP genes is between $88.0 \%$ to $98.7 \%$; for $\mathrm{M}$ genes is between $92.7 \%$ to $99.6 \%$ : for NS genes is between $92.1 \%$ to $98.9 \%$; for $\mathrm{PA}$ genes is between $86.1 \%$ to $94.1 \%$; for $\mathrm{Pb} 1$ genes is between $86.8 \%$ to $96.2 \%$; and for $\mathrm{Pb} 2$ genes is between $84.3 \%$ to $97.9 \%$.

This sequence comparison also shows that 9 nucleotides between nucleotide positions 205 and 214, lying between position 187 to 195 open reading (ORF) in the NA genes, are absent in these three Guangxi isolates (see Table 3) analyzed here. These 9 nucleotides encode for amino acids T, E, I. The deduced amino acid sequences of $\mathrm{HA}$ genes of $\mathrm{C} / \mathrm{GX} / 1 / 00$, $\mathrm{C} / \mathrm{GX} / 14 / 00$, and $\mathrm{C} / \mathrm{GX} / 17 / 00$ at the cleavage site of HA contain a PARSSR/GL motif, which denotes the sequence found in low pathogenicity avian influenza (LPAI) viruses, as described previously $[4,10,17]$.

3.3. Phylogenetic Analysis of Eight Genes. The phylogenetic relationship between each of the eight genes 
TABLE 2: Length of each gene of AIV C/GX/1/00, C/GX/14/00, C/GX/17/00, and virus with the greatest homology to each gene.

\begin{tabular}{|c|c|c|c|c|c|}
\hline Gene segment & Strain & Open reading frame & Length of peptides & Virus with greatest homology & Homology $(\%)$ \\
\hline \multirow{3}{*}{ HA } & $\mathrm{C} / \mathrm{GX} / 1 / 00$ & $34 \sim 1716$ & 560 & A/Chicken/Guangdong/4/00 & 99.3 \\
\hline & $\mathrm{C} / \mathrm{GX} / 14 / 00$ & $34 \sim 1716$ & 560 & A/Chicken/Guangdong/4/00 & 98.5 \\
\hline & $\mathrm{C} / \mathrm{GX} / 17 / 00$ & $34 \sim 1716$ & 560 & A/Chicken/Henan/26/00 & 99.2 \\
\hline \multirow{3}{*}{ NA } & $\mathrm{C} / \mathrm{GX} / 1 / 00$ & $20 \sim 1429$ & 469 & A/Chicken/Guangdong/4/00 & 97.0 \\
\hline & $\mathrm{C} / \mathrm{GX} / 14 / 00$ & $20 \sim 1420$ & 466 & A/Chicken/Jiangsu/1/00 & 97.7 \\
\hline & $\mathrm{C} / \mathrm{GX} / 17 / 00$ & $20 \sim 1429$ & 469 & A/Chicken/Jiangsu/1/00 & 97.7 \\
\hline \multirow{3}{*}{ NP } & $\mathrm{C} / \mathrm{GX} / 1 / 00$ & $39 \sim 1435$ & 498 & A/Chicken/Jiangsu/1/00 & 98.7 \\
\hline & $\mathrm{C} / \mathrm{GX} / 14 / 00$ & $39 \sim 1435$ & 498 & A/quail/Hongkong/G1/97 & 98.0 \\
\hline & $\mathrm{C} / \mathrm{GX} / 17 / 00$ & $39 \sim 1435$ & 498 & A/quail/Hongkong/G1/97 & 98.0 \\
\hline \multirow{3}{*}{ M } & $\mathrm{C} / \mathrm{GX} / 1 / 00$ & $26 \sim 784$ & 252 & A/Chicken/Guangdong/4/00 & 99.6 \\
\hline & $\mathrm{C} / \mathrm{GX} / 14 / 00$ & $26 \sim 784$ & 252 & A/Chicken/Guangdong/4/00 & 98.4 \\
\hline & $\mathrm{C} / \mathrm{GX} / 17 / 00$ & $26 \sim 784$ & 252 & A/Chicken/Guangdong/4/00 & 99.6 \\
\hline \multirow{3}{*}{ NS } & $\mathrm{C} / \mathrm{GX} / 1 / 00$ & $25 \sim 720$ & 231 & A/Chicken/Guangdong/47/01 & 98.9 \\
\hline & $\mathrm{C} / \mathrm{GX} / 14 / 00$ & $66 \sim 719$ & 217 & A/Chicken/Guangdong/4/00 & 98.7 \\
\hline & $\mathrm{C} / \mathrm{GX} / 17 / 00$ & $27 \sim 680$ & 217 & A/Chicken/Guangdong/4/00 & 98.5 \\
\hline \multirow{3}{*}{ PA } & $\mathrm{C} / \mathrm{GX} / 1 / 00$ & $25 \sim 2175$ & 716 & A/Chicken/Guangdong/47/01 & 94.0 \\
\hline & $\mathrm{C} / \mathrm{GX} / 14 / 00$ & $25 \sim 2175$ & 716 & A/Duck/Hongkong/Y439/97 & 93.8 \\
\hline & $\mathrm{C} / \mathrm{GX} / 17 / 00$ & $25 \sim 2175$ & 716 & A/Chicken/Guangdong/4/00 & 93.0 \\
\hline \multirow{3}{*}{$\mathrm{Pb} 1$} & $\mathrm{C} / \mathrm{GX} / 1 / 00$ & $22 \sim 2298$ & 758 & A/Chicken/Guangdong/4/00 & 96.2 \\
\hline & $\mathrm{C} / \mathrm{GX} / 14 / 00$ & $22 \sim 2298$ & 758 & A/Chicken/Jiangsu/1/00 & 95.9 \\
\hline & $\mathrm{C} / \mathrm{GX} / 17 / 00$ & $22 \sim 2298$ & 758 & A/Chicken/Guangdong/4/00 & 94.8 \\
\hline \multirow{3}{*}{$\mathrm{Pb} 2$} & $\mathrm{C} / \mathrm{GX} / 1 / 00$ & $25 \sim 2304$ & 759 & A/Chicken/Jilin/53/01 & 95.5 \\
\hline & $\mathrm{C} / \mathrm{GX} / 14 / 00$ & $25 \sim 2304$ & 759 & A/Hongkong/1047/99 & 92.4 \\
\hline & $\mathrm{C} / \mathrm{GX} / 17 / 00$ & $25 \sim 2304$ & 759 & A/quail/Hongkong/G1/97 & 97.9 \\
\hline
\end{tabular}

from three isolates, $\mathrm{C} / \mathrm{GX} / 1 / 00, \mathrm{C} / \mathrm{GX} / 14 / 00$, and $\mathrm{C} /$ $\mathrm{GX} / 17 / 00$, was analyzed based on their nucleotide sequence (Figures 1-8). The analysis indicates that there are three sublineages in the Eurasian lineage as described previously [4, $10,18]$. The NP and $\mathrm{Pb} 1$ genes of $\mathrm{C} / \mathrm{GX} / 14 / 00$ and $\mathrm{NP}, \mathrm{Pb} 1$, $\mathrm{Pb} 2$ genes of $\mathrm{C} / \mathrm{GX} / 17 / 00$ were incorporated into the sublineage represented by A/Quail/Hongkong/G1/97 (see Figures 4, 7, and 8). The HA, M, NP, Pb1, $\mathrm{Pb} 2$ genes of $\mathrm{C} / \mathrm{GX} / 1 / 00$, the $\mathrm{HA}$ and $\mathrm{M}$ genes of $\mathrm{C} / \mathrm{GX} / 14 / 00$, and $\mathrm{HA}$ and $\mathrm{M}$ genes of $\mathrm{C} / \mathrm{GX} / 17 / 00$ were incorporated into the sublineage represented by A/duck/Hongkong/Y280/97 (see Figures 1, 2, and 3 ). No gene of the three isolates was incorporated into the sublineage represented by A/duck/Hongkong/Y439/97. The PA, NA, NS genes of C/GX/1/00, NA, PA, NS, Pb2 genes of $\mathrm{C} / \mathrm{GX} / 14 / 00$, and the NA, NS, PA genes of C/GX/17/00 were not incorporated into any of sublineage of these three isolates (see Figures 4, 5, 6, and 8).

\section{Discussion}

AIV has a segmented negative-strand genome that includes $\mathrm{HA}, \mathrm{NA}, \mathrm{M}, \mathrm{NS}, \mathrm{NP}, \mathrm{PA}, \mathrm{Pb} 1, \mathrm{~Pb} 2$ genes. The results of sequencing and comparisons with the other H9N2 virus sequences showed that we have obtained each of eight genes from three Chinese isolates, C/GX/1/00, C/GX/14/00, and C/GX/17/00 successfully.
Previous studies have defined two distinct lineages of H9N2 influenza viruses: North American and Eurasian lineages. The Eurasian lineage consists of at least three sublineages [7, 13, 14]. Phylogenetic analysis in our study showed similar patterns (Figures 1-8). Viral genomes of H9N2 viruses analyzed in previous studies had shown a common source of origin from southern China $[6,9,10,18]$. Sequence comparison and phylogenetic analysis illustrated that $\mathrm{NP}$ and $\mathrm{Pb} 1$ genes of $\mathrm{C} / \mathrm{GX} / 14 / 00$, and $\mathrm{NP}, \mathrm{Pb} 1$, and $\mathrm{Pb} 2$ genes of $\mathrm{C} / \mathrm{GX} / 17 / 00$ were incorporated into the sublineage represented by A/Quail/Hongkong/G1/97. HA, $\mathrm{M}, \mathrm{NP}, \mathrm{Pb} 1$, and $\mathrm{Pb} 2$ genes of $\mathrm{C} / \mathrm{GX} / 1 / 00, \mathrm{HA}$ and $\mathrm{M}$ genes of $\mathrm{C} / \mathrm{GX} / 14 / 00$, and $\mathrm{HA}$ and $\mathrm{M}$ genes of $\mathrm{C} / \mathrm{GX} / 17 / 00$ were incorporated into the sublineage represented by A/duck/Hongkong/Y280/97. None of the genes from these three isolates was incorporated into the sublineage represented by A/duck/Hongkong/Y439/97. PA, NA, and NS genes of $\mathrm{C} / \mathrm{GX} / 1 / 00, \mathrm{NA}, \mathrm{PA}, \mathrm{NS}$, and $\mathrm{Pb} 2$ genes of $\mathrm{C} / \mathrm{GX} / 14 / 00$, and the NA, NS, and PA genes of C/GX/17/00 were not incorporated into any of the sublineages. So, it is possible that AIV H9N2 subtype strains C/GX/1/00, C/GX/14/00, and $\mathrm{C} / \mathrm{GX} / 17 / 00$ were products of natural reassortment of avian influenza viruses, suggesting that there may be a specific gene pool in China, as described by Lu et al. [18].

Interestingly, gene sequence comparison indicates that there is a 9-nucleotide deletion between nucleotides 205 and 214 ( 187 position to 195 position of ORF) in the NA genes of 
TABLE 3: Comparison of ORF nucleotide sequences of NA gene; $\mathrm{nt}=$ nucleotide .

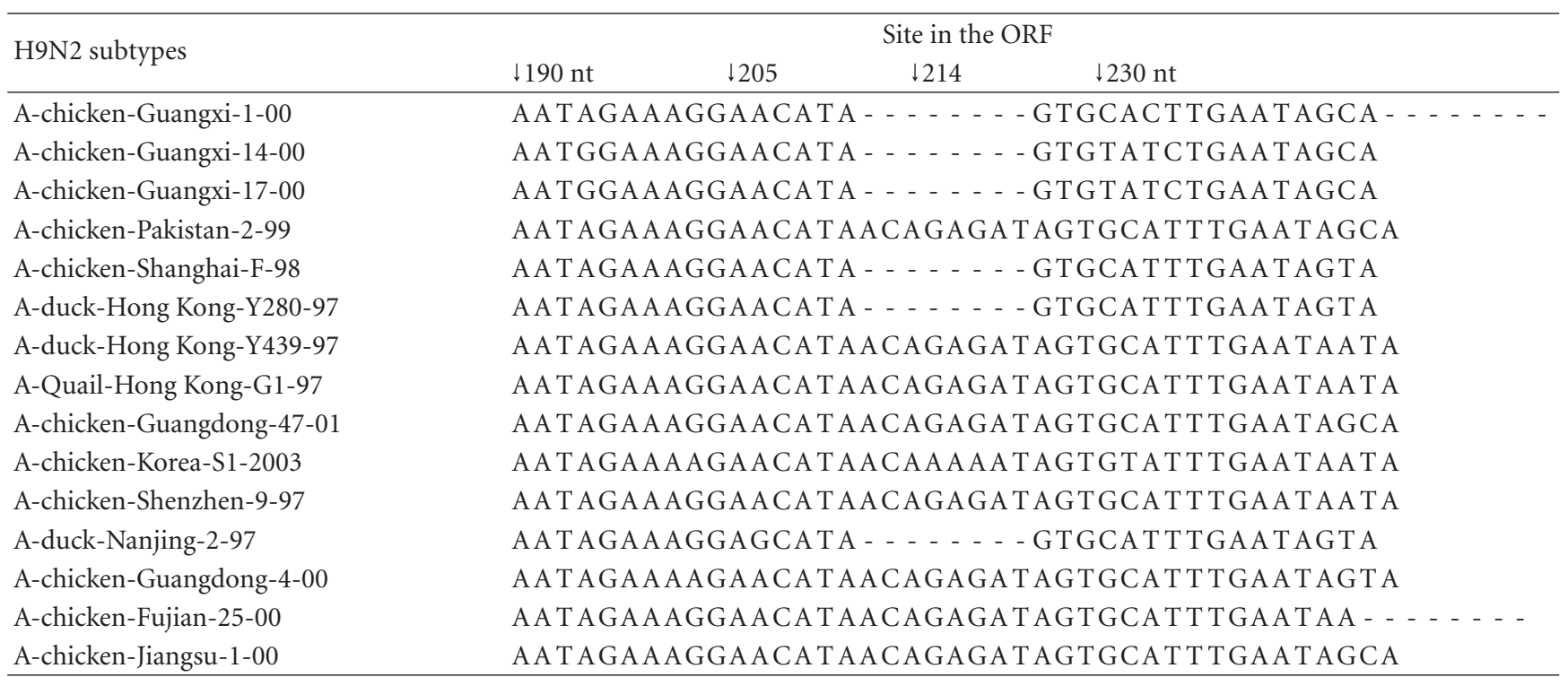

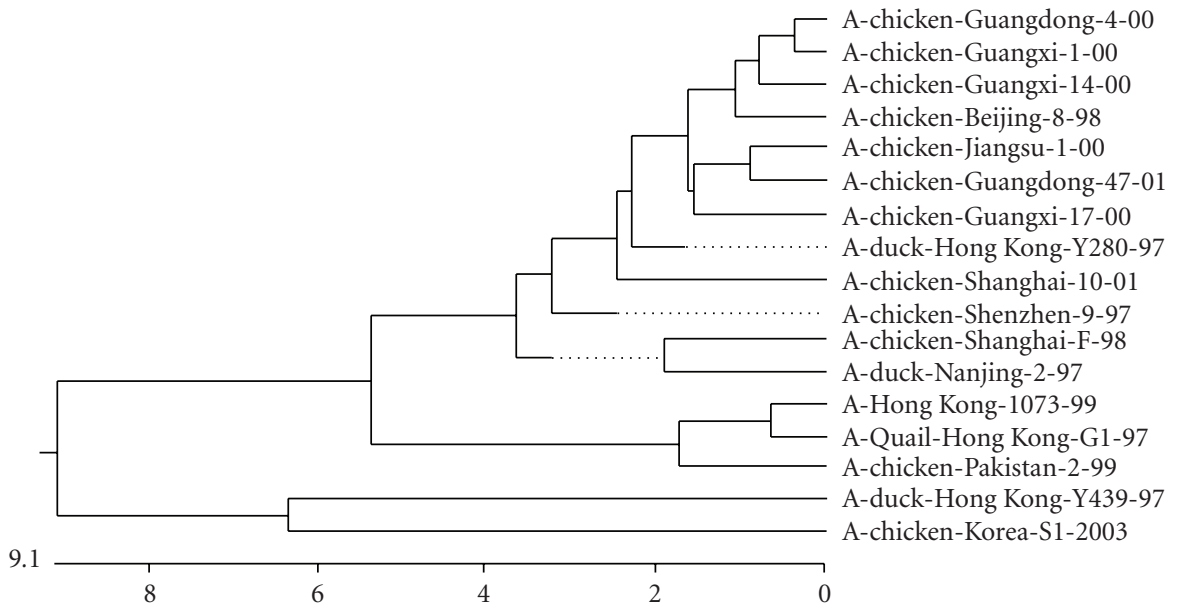

FIgURE 1: Phylogenetic tree of HA gene of AIV.

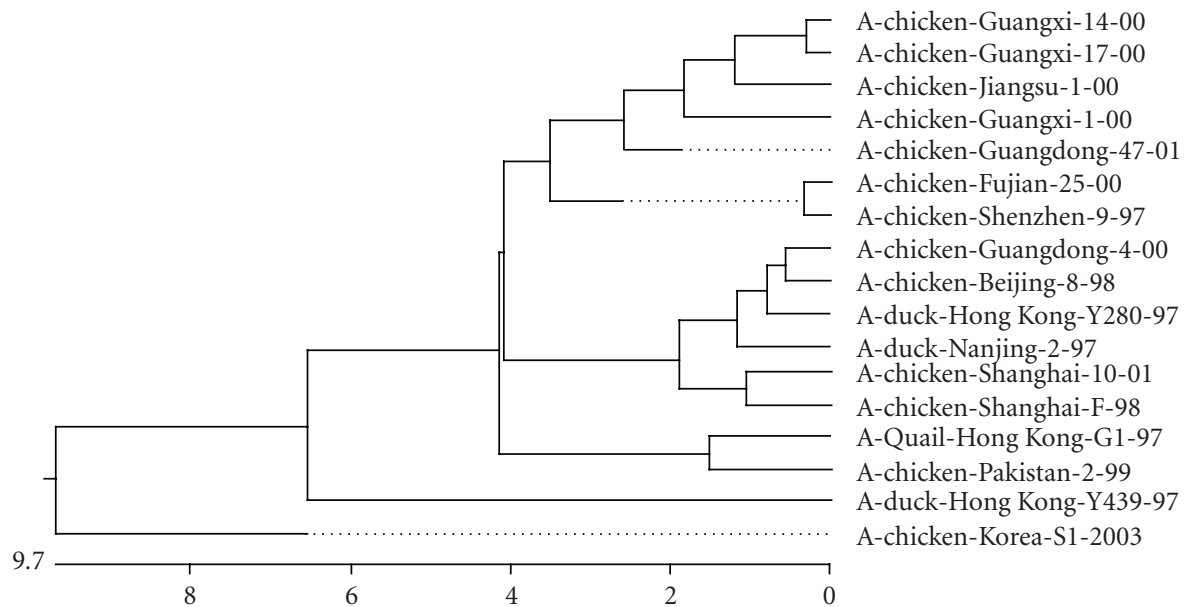

FIgure 2: Phylogenetic tree of NA gene of AIV. 


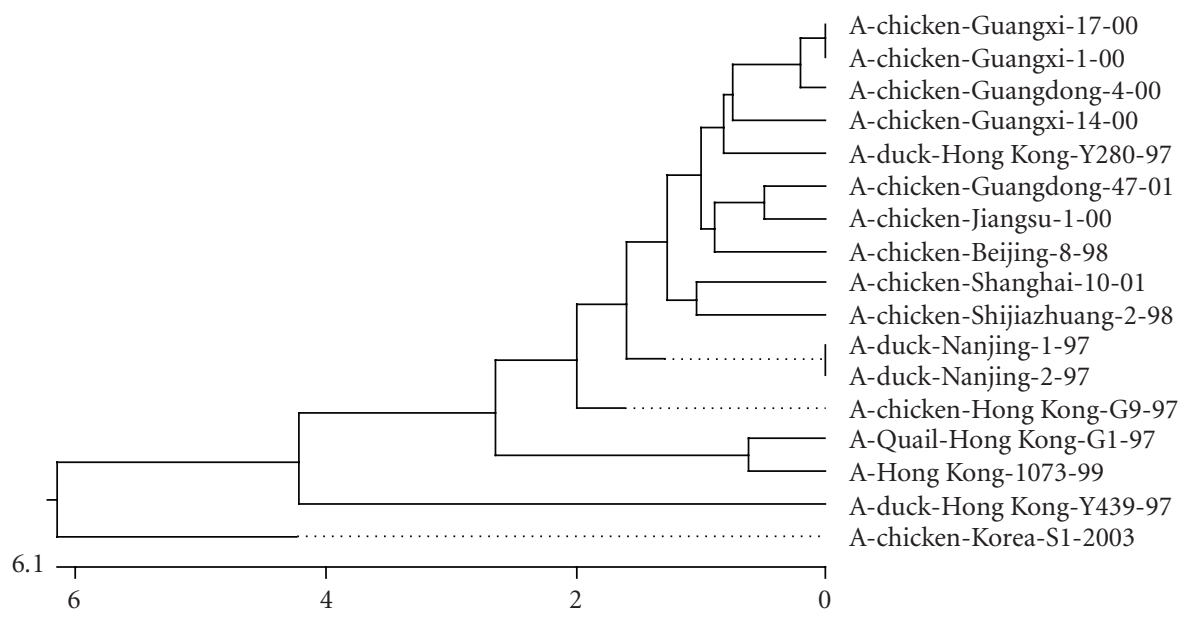

FIgure 3: Phylogenetic tree of M gene of AIV.

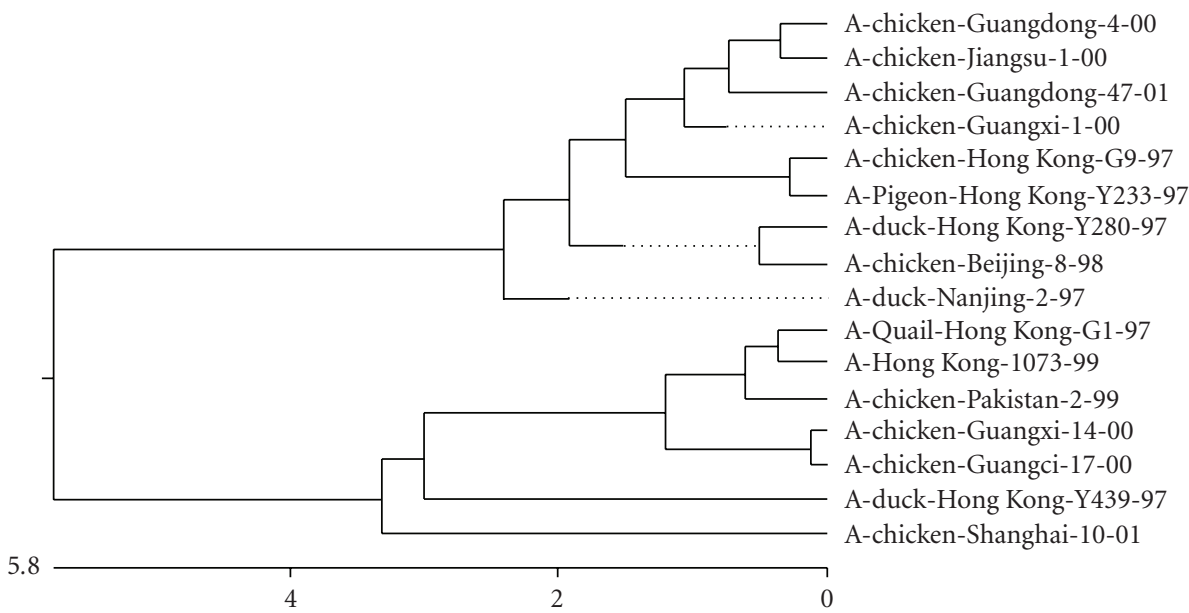

FIgUre 4: Phylogenetic tree of NP gene of AIV.

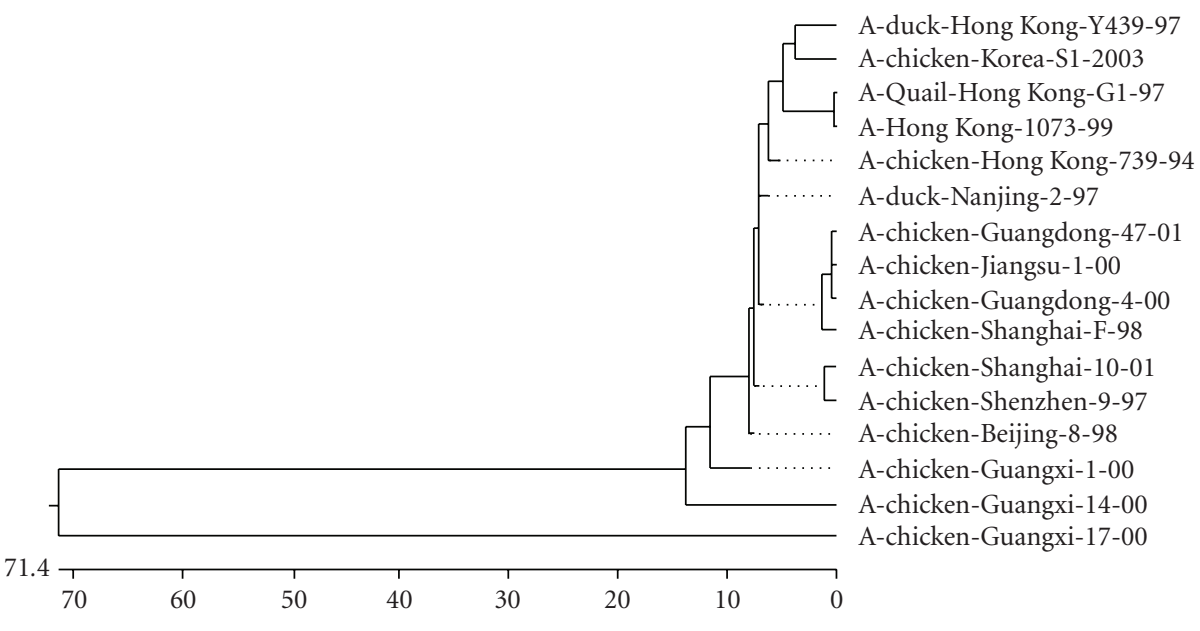

Figure 5: Phylogenetic tree of NS gene of AIV. 


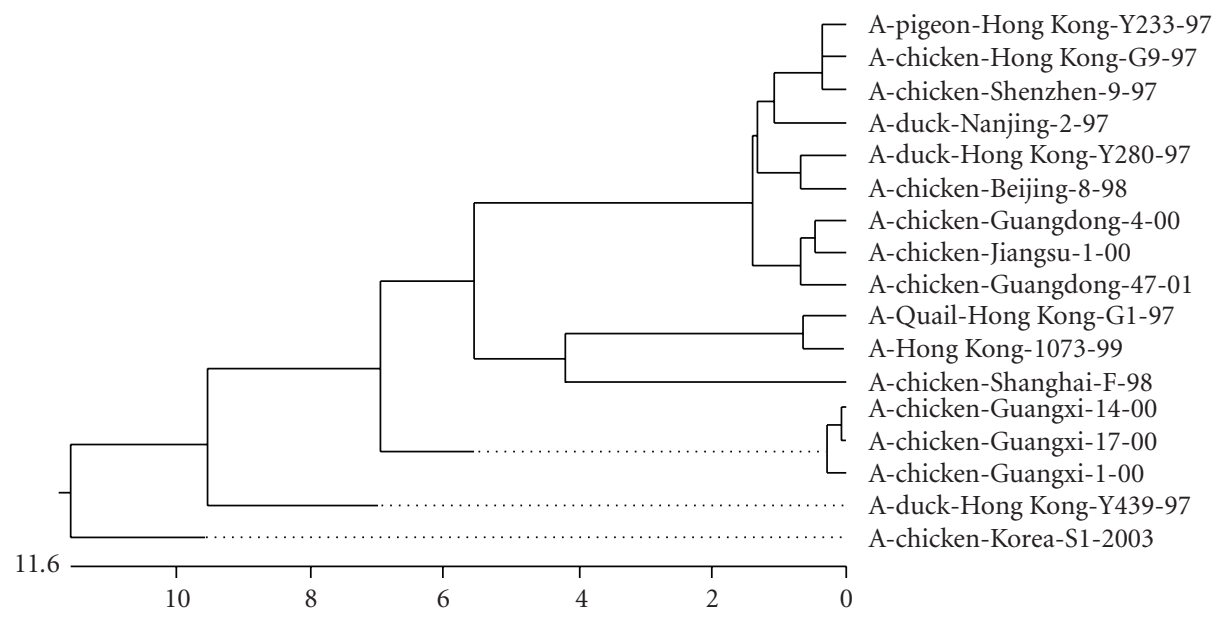

Figure 6: Phylogenetic tree of PA gene of AIV.

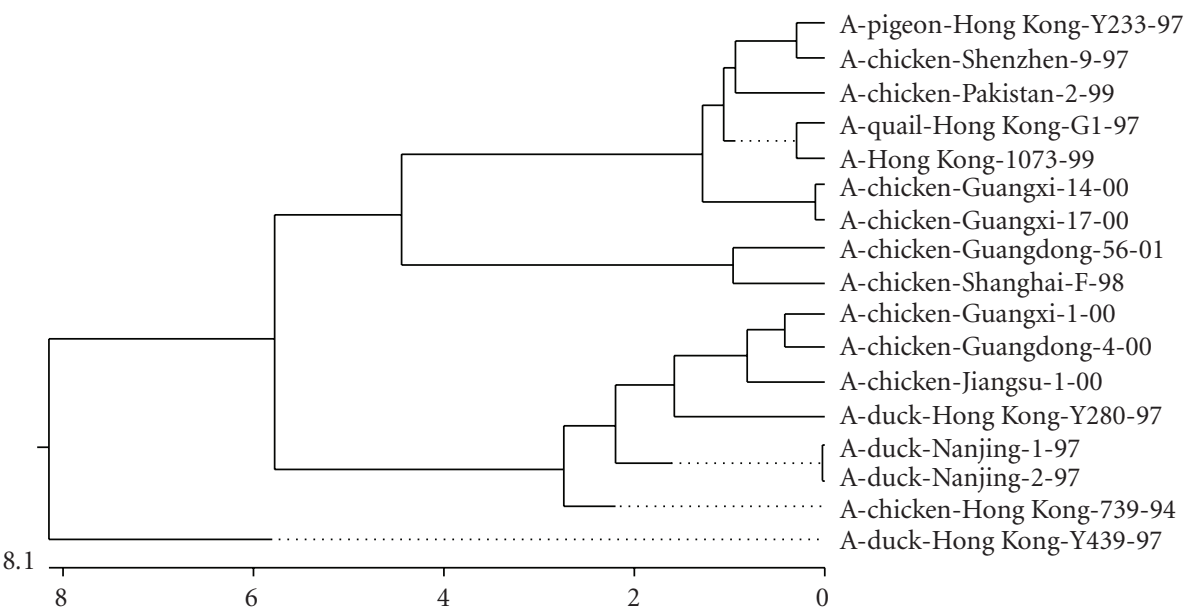

Figure 7: Phylogenetic tree of $\mathrm{Pb} 1$ gene of AIV.

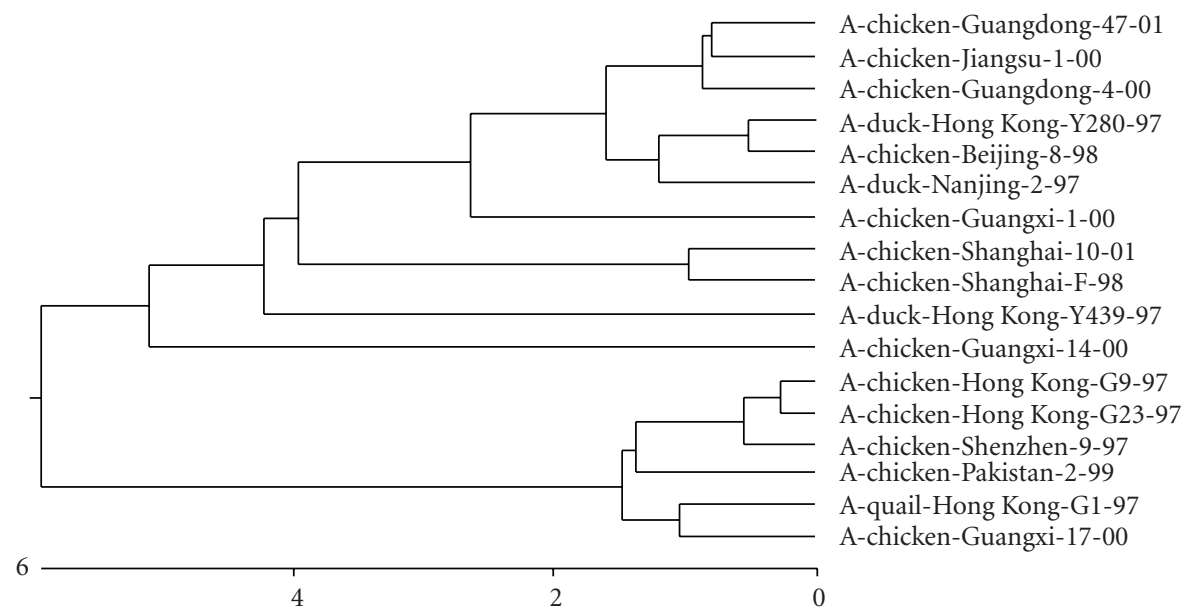

Figure 8: Phylogenetic tree of $\mathrm{Pb} 2$ gene of AIV. 
the three isolates $\mathrm{C} / \mathrm{GX} / 1 / 00, \mathrm{C} / \mathrm{GX} / 14 / 00$, and $\mathrm{C} / \mathrm{GX} / 17 / 00$. These 9 nucleotides encode for amino acids $\mathrm{T}, \mathrm{E}$, and $\mathrm{I}$. This deletion did not change the ORF of the NA gene. Noteworthy, about $80 \%$ of China mainland isolates carry a similar deletions. Further studies are needed to determine if the lack of 9 nucleotides in NA affects the function of the NA protein.

HA protein determines the infectious host range of AIV strains. AIV strains infecting humans carry leucine at position 226 of the HA gene [7, 13, 14]. The analysis of deduced amino acid sequence of HA proteins of $\mathrm{C} / \mathrm{GX} / 1 / 00$, $\mathrm{C} / \mathrm{GX} / 14 / 00$, and $\mathrm{C} / \mathrm{GX} / 17 / 00$ isolates showed a glycine at position 226, therefore these three isolates do not belong to H9N2 AIV strains isolated from human infections.

\section{Acknowledgments}

This study was supported by Guangxi Science and Technology Bureau (Grant no. GKG0235001-4), studying abroad fund of Guangxi province (Grant no. GKH0236005), and Guangxi Husbandry and Fisheries Bureau. The authors thank Dr. Antonio Garmendia for his constructive suggestions and critical review of the manuscript.

\section{References}

[1] D. J. Alexander, "Avian influenza: recent developments," Veterinary Bulletin, vol. 52, no. 6, pp. 341-359, 1982.

[2] R. G. Webster, W. J. Bean, O. T. Gorman, T. M. Chambers, and Y. Kawaoka, "Evolution and ecology of influenza A viruses," Microbiological Reviews, vol. 56, no. 1, pp. 152-179, 1992.

[3] K. M. Butt, G. J. D. Smith, H. Chen, et al., "Human infection with an avian H9N2 influenza A virus in Hong Kong in 2003," Journal of Clinical Microbiology, vol. 43, no. 11, pp. 5760-5767, 2005.

[4] Y. J. Guo, S. Krauss, D. A. Senne, et al., "Characterization of the pathogenicity of members of the newly established H9N2 influenza virus lineages in Asia," Virology, vol. 267, no. 2, pp. 279-288, 2000.

[5] H.-J. Kwon, S.-H. Cho, M.-C. Kim, Y.-J. Ahn, and S.-J. Kim, "Molecular epizootiology of recurrent low pathogenic avian influenza by H9N2 subtype virus in Korea," Avian Pathology, vol. 35, no. 4, pp. 309-315, 2006.

[6] K. S. Li, K. M. Xu, S. M. Peiris, et al., "Characterization of H9 subtype influenza viruses from the ducks of southern China: a candidate for the next influenza pandemic in humans?" Journal of Virology, vol. 77, no. 12, pp. 6988-6994, 2003.

[7] M. N. Matrosovich, S. Krauss, and R. G. Webster, "H9N2 influenza A viruses from poultry in Asia have human viruslike receptor specificity," Virology, vol. 281, no. 2, pp. 156-162, 2001.

[8] M. Peiris, K. Y. Yuen, C. W. Leung, et al., "Human infection with influenza H9N2," The Lancet, vol. 354, no. 9182, pp. 916917, 1999.

[9] Y. K. Choi, H. Ozaki, R. J. Webby, et al., "Continuing evolution of H9N2 influenza viruses in southeastern China," Journal of Virology, vol. 78, no. 16, pp. 8609-8614, 2004.

[10] H. Liu, X.-F. Liu, J. Cheng, D. Peng, L. Jia, and Y. Huang, "Phylogenetic analysis of the hemagglutinin genes of twentysix avian influenza viruses of subtype H9N2 isolated from chickens in China during 1996-2001," Avian Diseases, vol. 47, no. 1, pp. 116-127, 2003.

[11] J.-H. Liu, K. Okazaki, W.-M. Shi, Q.-M. Wu, A. S. Mweene, and H. Kida, "Phylogenetic analysis of neuraminidase gene of H9N2 influenza viruses prevalent in chickens in China during 1995-2002," Virus Genes, vol. 27, no. 2, pp. 197-202, 2003.

[12] S. Wang, W.-M. Shi, A. Mweene, H.-L. Wei, G.-R. Bai, and J.-H. Liu, "Genetic analysis of the nonstructural (NS) genes of H9N2 chicken influenza viruses isolated in China during 1998-2002," Virus Genes, vol. 31, no. 3, pp. 329-335, 2005.

[13] Y. Guan, K. F. Shortridge, S. Krauss, et al., "H9N2 influenza viruses possessing $\mathrm{H} 5 \mathrm{~N} 1$-like internal genomes continue to circulate in poultry in southeastern China," Journal of Virology, vol. 74, no. 20, pp. 9372-9380, 2000.

[14] Y. P. Lin, M. Shaw, V. Gregory, et al., "Avian-to-human transmission of H9N2 subtype influenza A viruses: relationship between H9N2 and H5N1 human isolates," Proceedings of the National Academy of Sciences of the United States of America, vol. 97, no. 17, pp. 9654-9658, 2000.

[15] World Health Organization, "A revision of the system of nomenclature for influenza viruses: a WHO memorandum," Bulletin of the World Health Organization, vol. 58, no. 4, pp. 585-591, 1980.

[16] Z. Xie, Y. Pang, J. Liu, et al., "A multiplex RT-PCR for detection of type A influenza virus and differentiation of avian H5, H7, and H9 hemagglutinin subtypes," Molecular and Cellular Probes, vol. 20, no. 3-4, pp. 245-249, 2006.

[17] D. A. Steinhauer, "Role of hemagglutinin cleavage for the pathogenicity of influenza virus," Virology, vol. 258, no. 1, pp. 1-20, 1999.

[18] J.-H. Lu, X.-F. Liu, W.-X. Shao, Y.-L. Liu, D.-P. Wei, and H.-Q. Liu, "Phylogenetic analysis of eight genes of H9N2 subtype influenza virus: a mainland China strain possessing early isolates' genes that have been circulating," Virus Genes, vol. 31, no. 2, pp. 163-169, 2005. 